Review

\title{
Variable Speed Diesel Electric Generators: Technologies, Benefits, Limitations, Impact on Greenhouse Gases Emissions and Fuel Efficiency
}

\author{
Raisa Barbosa ${ }^{1,}{ }^{*}$, Mohamad Issa $^{1}$, Sidelmo Silva ${ }^{2}$, Adrian Ilinca ${ }^{1}$
}

1. Laboratoire de Recherche en Énergie Éolienne, Université du Québec à Rimouski, 300 allée des ursulines, Rimouski, Québec G5L 3A1, Canada; E-Mails: raisa.diasbarbosa@uqar.ca; adrian ilinca@uqar.ca; Mohamad Issa@uqar.ca

2. Universidade Federal de Minas Gerais, Av. Pres. Antônio Carlos, 6627-Pampulha, Belo HorizonteMG, 31270-901, Brazil; E-Mail: sidelmo@eee.ufmg.br

* Correspondence: Raisa Barbosa; E-Mail: raisa.diasbarbosa@uqar.ca

Academic Editor: Andrés Elías Feijóo Lorenzo

Collection: Wind Energy

Journal of Energy and Power Technology

2022, volume 4, issue 1

doi:10.21926/jept.2201003
Received: July 30, 2021

Accepted: January 04, 2022

Published: January 13, 2022

\begin{abstract}
A substantial share of the electric energy is generated with synchronous generators that provide sustained alternating current $(A C)$ voltage and frequency energy to regional and national power systems, which subsequently transport and distribute it to diverse users. In an attempt to reduce environmental effects, electric energy markets have recently become more open, resulting in more flexible distributed electric power systems. In such distributed systems, stability, quick and efficient delivery, and control of electric power require some degree of power electronics control to allow for lower power in the electric generators to tap the primary fuel energy potential better and increase efficiency and stability. This is how variable-speed electric generators (VSEG) recently came into play, up to the 400-megavolt ampere (MVA)/ unit size, and which have been at work since 1996. This paper provides coverage of variable-speed electric diesel generators (VSDEG) in distributed generation and their impacts on fuel efficiency and greenhouse gases (GHG). It discusses permanent-magnet(PM) synchronous generators, solutions based on power electronics such as diesel-driven
\end{abstract}

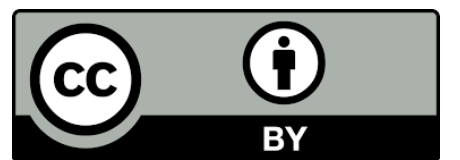

(C) 2022 by the author. This is an open access article distributed under the conditions of the Creative Commons by Attribution License, which permits unrestricted use, distribution, and reproduction in any medium or format, provided the original work is correctly cited. 
wound-rotor-induction generator, doubly-fed-induction generator (DFIG), rotating stator generator, and the application of continuously variable transmission to a VSEG. The benefits and limitations of the selected technologies are also presented. The list of references given at the end of the paper should offer aids for students and researchers working in this field.

\section{Keywords}

Diesel generator; variable speed diesel generator (VSDG); energy efficiency; fuel efficiency; greenhouse gases (GHG); permanent-magnet synchronous generator; DFIG

\section{Introduction}

Environmental concerns and the search for reduced greenhouse gas emissions have encouraged the rapid development of renewable energy technologies to produce electricity. However, fossil fuel generators are indispensable as autonomous sources of primary power supply or reserve for marine vessels and onshore facilities [1-3].

Diesel Engine Generators (DEG) are widely used in isolated regions because they have high reliability, stability, long service life, and ease of production [4-6]. These advantages justify the preference for this energy source over renewable energies for these applications, which, despite technological advances, are unpredictable, intermittent, and have limited storage capacity $[7,8]$. However, the high fuel consumption in DEGs is a disadvantage, as this consumption represents an increased emission of greenhouse gases. According to [9], only one-kilogram diesel-burning leads to nearly 3-kilogram greenhouse gas emissions. Furthermore, the incomplete combustion of diesel is responsible for the emission of hazardous and destructive gases to the environment, in addition to the emission of particles that contribute to air pollution [10-14]. This is more apparent when the diesel generator is operated at a low charge for an extended period, causing combustion wastes to condense on the engine cylinder walls, increasing friction, decreasing efficiency, and increasing fuel consumption [5]. Another disadvantage of DEG systems is the fluctuation of fuel price and the high costs of transportation to isolated regions, which increase the cost of electricity [15-19]. Many studies have been carried out to reduce fuel consumption and pollution, as well as to improve the efficiency of the generation system [20-23]. Furthermore, it is anticipated that fossil fuels will deplete within the next 40-50 years, as illustrated in Figure 1. 


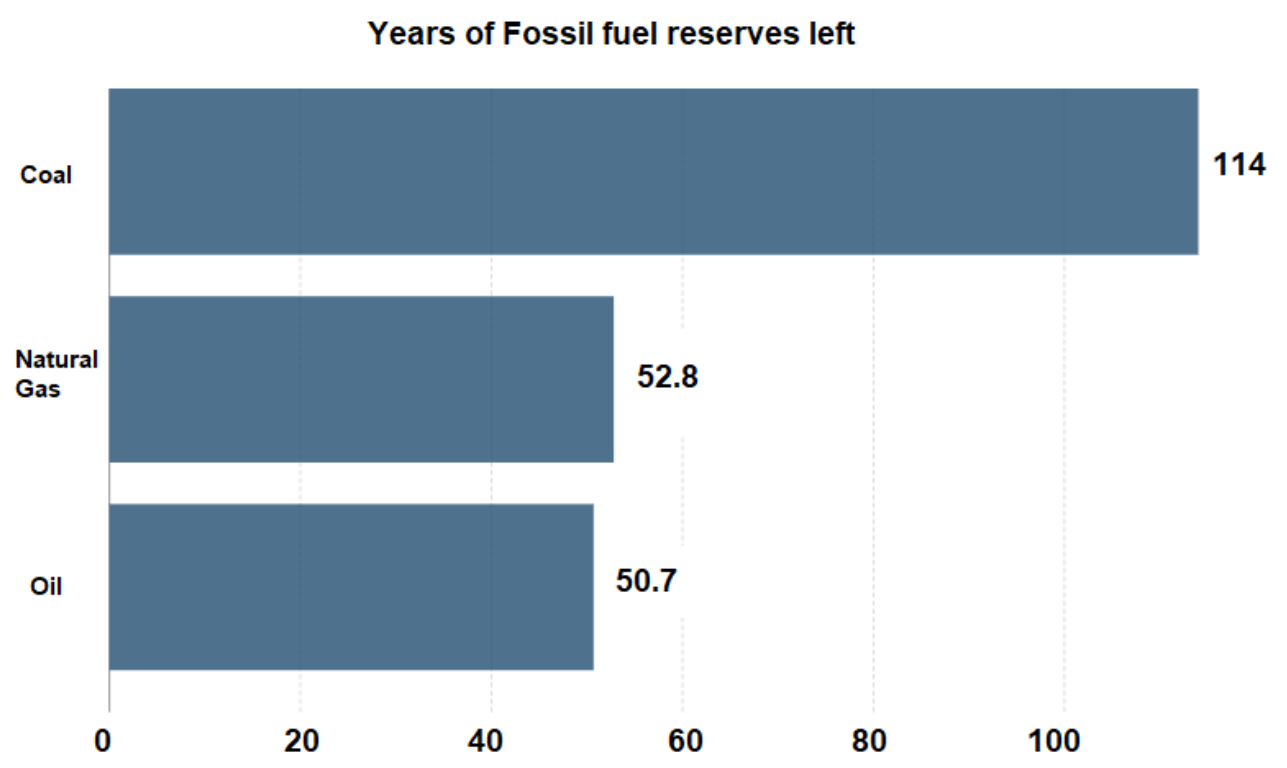

Figure 1 Years of global coal, oil, and natural gas availability based on known reserves and annual production levels in 2015 . Note that these values can change in time based on new reserves and changes in annual production.

Traditional Generator sets powered by DEGs (Genset) typically work at a fixed speed to provide reliable synchronous speed for the electric power generators. Therefore, The DEGs are sized to provide the peak of local load demand, presenting a nominal power due to this peak demand. Although the DEG has maximum efficiency when operating at rated capacity, its efficiency decreases considerably when working in low load regimes [19]. Thus, efficiency is compromised in regions where Gensets operate continuously, and there is a significant difference between the low load, with high duration, and the peak load, which usually occurs during a short period. In addition, low load operation increases the fuel consumption, increasing fuel costs and the machine maintenance frequency, which wears out faster when not operating at rated power [24].

This work aims to present the leading diesel generator technologies operating at variable speed, highlighting the advantages and disadvantages of each and showing their impacts on fuel efficiency and greenhouse gases (GHGs). A comparison between the studied technologies will also be presented according to the possible applications.

Section 2 presents the power conversion systems at fixed and variable speeds. Section 3 presents the characteristics of power generation technologies at a fixed speed and variable speed. Section 4 describes diesel generator technologies at variable speed discussed in the literature, while section 5 compares these technologies concerning system efficiency, fuel consumption, and emissions of gases and particles into the atmosphere. Finally, section 6 presents the conclusion of this work.

\section{Power Conversion Systems at Fixed and Variable Speeds}

\subsection{Fixed Speed Diesel Generator (FSDG)}

In DEG systems operating at a fixed speed, the diesel engine runs at a constant speed to provide specific mechanical torque for an electric power generator without monitoring the variation of the electric charge or the engine efficiency [24]. The advantages of this topology are the robustness and 
simplicity of construction and operation (which implies a reduced cost). The disadvantage is that in an FSDG, as the load decreases, to maintain the fixed speed required by a fixed frequency and voltage amplitude, the rotor will operate with a high mechanical torque uselessly [25] (Figure 2). The diesel engine, which is connected directly to the rotor shaft of the generator, must provide mechanical torque appropriate to the load level to maintain quality power production [26]. In other words, as the load decreases, in an FSDG, the DEG will operate less efficiently to maintain a fixed speed, which implies higher fuel consumption for a low load regime, i.e., between 30 and $40 \%$ of the rated load [27]. In addition, fixed speed operation generates more significant mechanical efforts on the system, increasing the risk of failure. Moreover, the high maintenance rate affects the system during low load operations due to cylinder glazing or, in worse cases, piston locking [28]. Figure 3 shows a diagram representation of this technology.
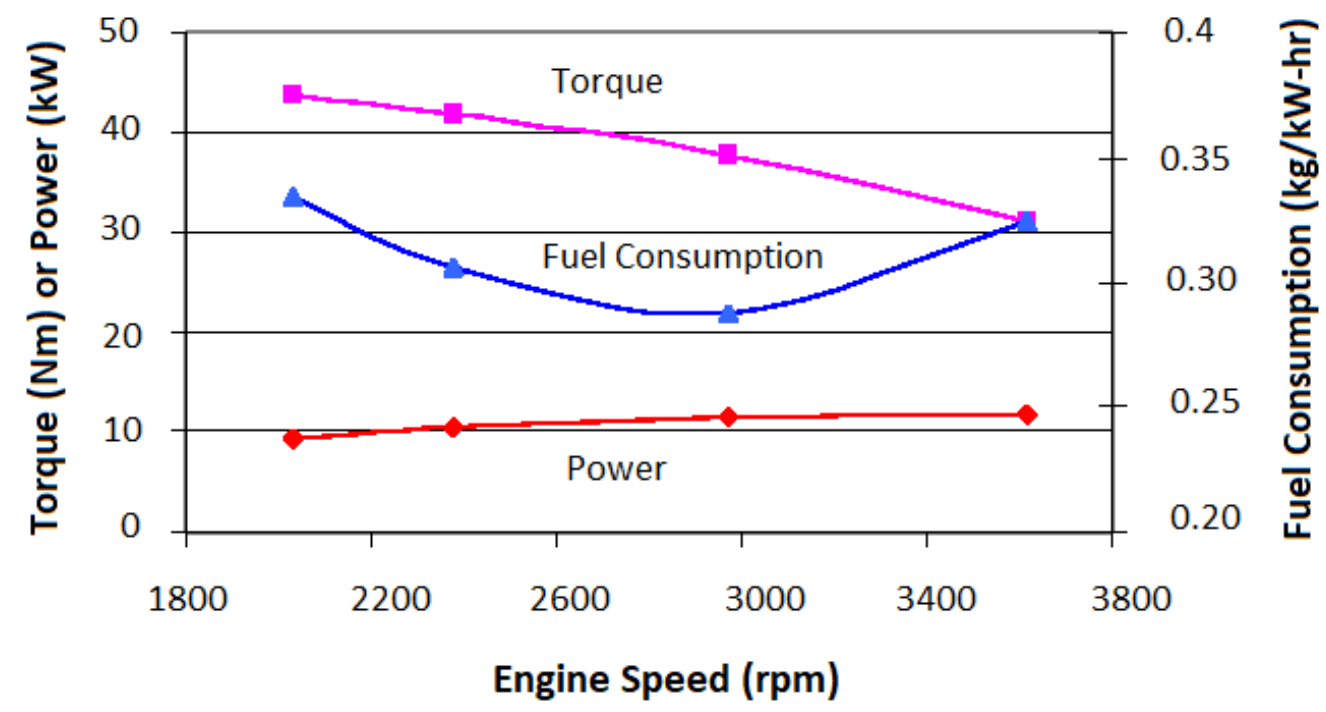

Figure 2 The diesel engine's peak torque, power, and fuel consumption in a proof-ofconcept Genset.

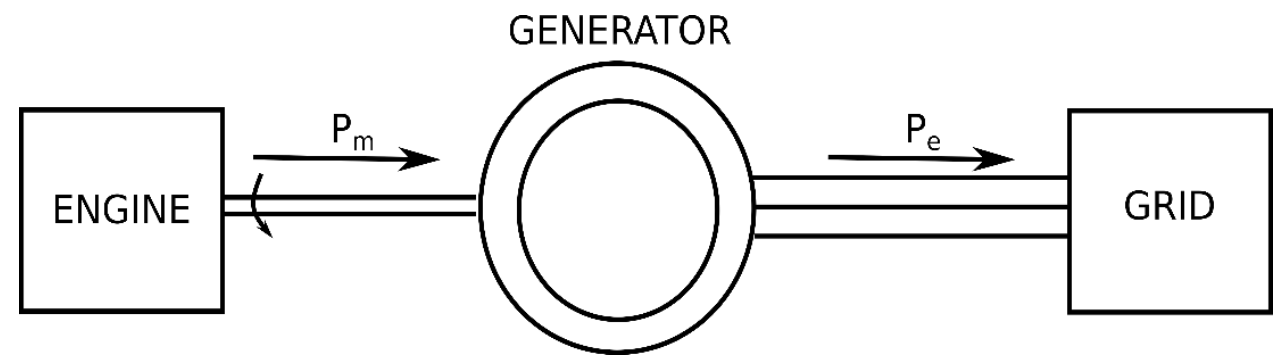

Figure 3 Fixed Speed Diesel Generator diagram.

These systems are designed for a limited variation of the speed range to optimize their efficiency, typically presenting two rotation speeds. This is possible by using two generators of different numbers of poles and different rated powers $[28,29]$ or by using only one generator with the possibility of varying the number of poles. Either way, using two rotational speeds allows for a relative efficiency increase. Furthermore, the rated rotational speeds are chosen to optimize the fulfillment of the local demand due to the characteristic load curve of the system. 


\subsection{Variable Speed Diesel Generator (VSDG)}

The operation at variable speed allows the search for operating conditions that promote the maximum efficiency of the power generation system. This is because the rotation speed affects the consumption of the engine when the mechanical load decreases according to the electrical load, as seen in Figure 4.

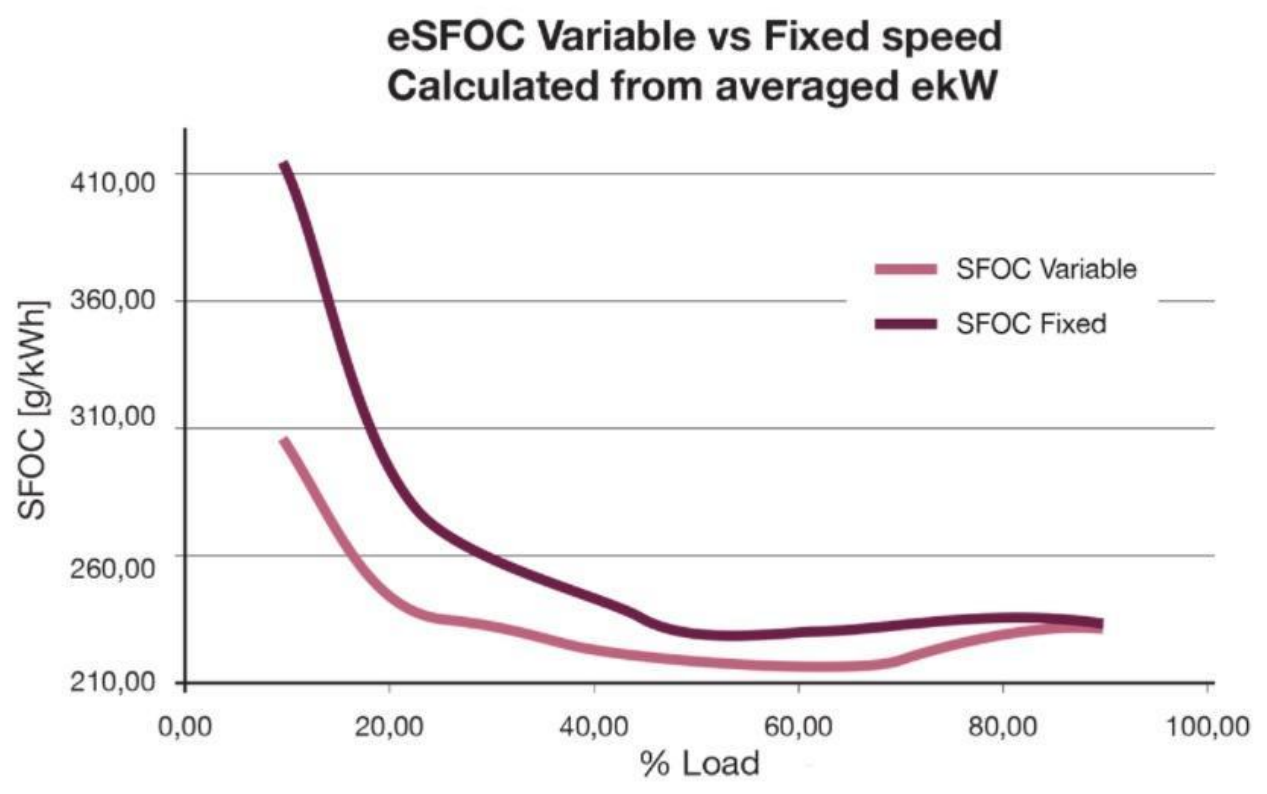

Figure 4 Two Specific Fuel Oil Consumption (SFOC) for variable and fixed speed dieseldriven electric generator $3516 \mathrm{C}$ rated at $2350 \mathrm{~kW}$.

In the VSDG, the mechanical torque provided by the DEG is adjusted according to the demand of the load. Therefore, when the system operates under a low load, the DEG slows down, avoiding the unnecessary production of mechanical torque. As seen in Figure 4, the results show a $27 \%$ fuel saving at $10 \%$ load down to $3,5 \%$ fuel saving at $80 \%$ load when running the engine at variable speed from 1,200 RPM to 1,800 RPM.

Figure 5 indicates the Genset scheme with a Variable Speed Diesel Generator system.

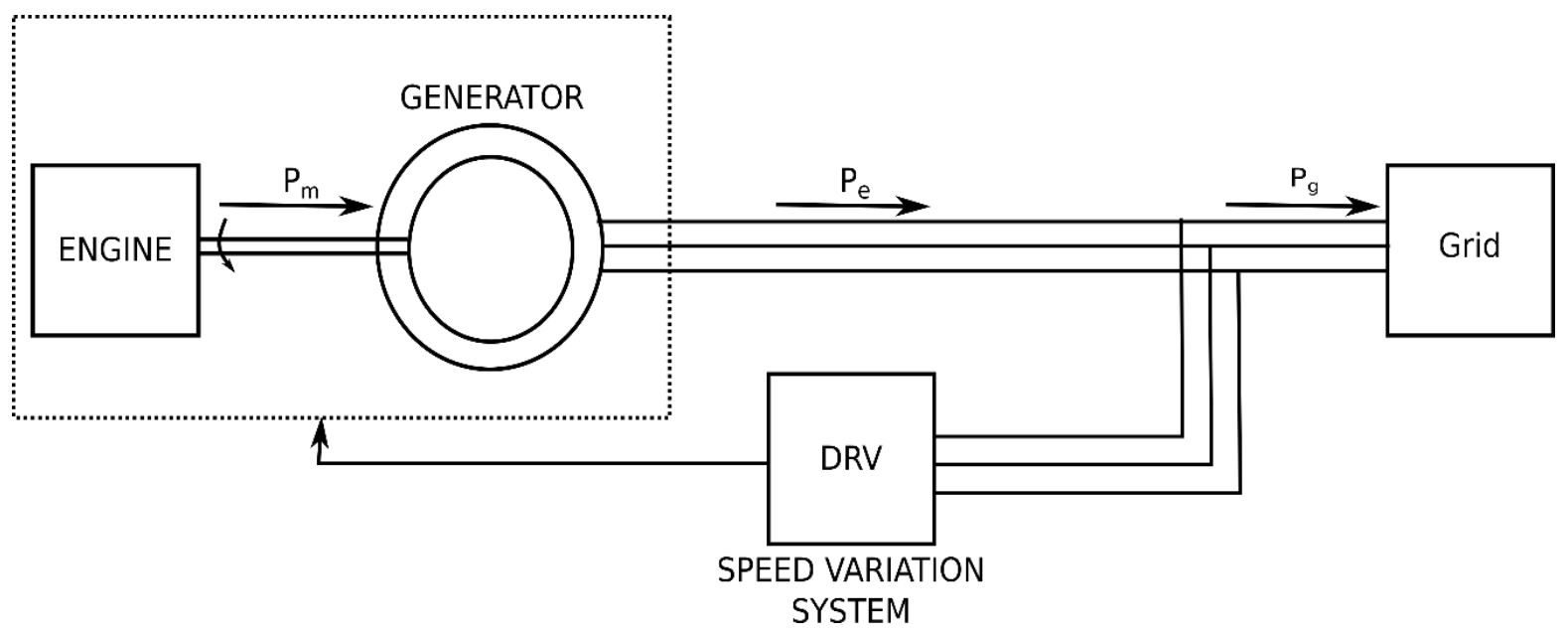

Figure 5 Variable Speed Diesel Generator diagram. 
Generation systems that operate at variable speed have many advantages over systems operating at a fixed speed [29]. Although these systems have a higher initial investment than FSDG systems, this cost is justifiable when considering improving fuel efficiency [30] and reducing greenhouse gas (GHG) emissions. A comparison between typical GHG emissions from a 500kW FSDG vs. VSDG at different load levels is presented in Table 1 [1].

Table 1 Improved GHG emission at different load levels for a 500kW FSDG versus a VSDG using ultra-low sulfur diesel fuel $(0,1 \% \mathrm{~S})[1]$.

\begin{tabular}{|c|c|c|c|c|}
\hline Gases & Applied Load & FSDG & VSDG & Difference (\%) \\
\hline & $25 \%$ & 107 kg/hr & $90 \mathrm{~kg} / \mathrm{hr}$ & $15,9 \%$ \\
\hline \multirow[t]{4}{*}{$\mathrm{CO} 2$} & $50 \%$ & $203 \mathrm{Kg} / \mathrm{hr}$ & $191 \mathrm{Kg} / \mathrm{hr}$ & $5,9 \%$ \\
\hline & $75 \%$ & $300 \mathrm{Kg} / \mathrm{hr}$ & $274 \mathrm{Kg} / \mathrm{hr}$ & $8,6 \%$ \\
\hline & $100 \%$ & $389 \mathrm{Kg} / \mathrm{hr}$ & $359 \mathrm{Kg} / \mathrm{hr}$ & $7,7 \%$ \\
\hline & $25 \%$ & $0,17 \mathrm{~kg} / \mathrm{hr}$ & $0,14 \mathrm{~kg} / \mathrm{hr}$ & $17,6 \%$ \\
\hline \multirow[t]{4}{*}{ SOx } & $50 \%$ & $0,32 \mathrm{Kg} / \mathrm{hr}$ & $0,29 \mathrm{Kg} / \mathrm{hr}$ & $9,4 \%$ \\
\hline & $75 \%$ & $0,44 \mathrm{Kg} / \mathrm{hr}$ & $0,42 \mathrm{Kg} / \mathrm{hr}$ & $4,5 \%$ \\
\hline & $100 \%$ & $0,60 \mathrm{Kg} / \mathrm{hr}$ & $0,56 \mathrm{Kg} / \mathrm{hr}$ & $6,6 \%$ \\
\hline & $25 \%$ & $0,08 \mathrm{~kg} / \mathrm{hr}$ & $0,06 \mathrm{~kg} / \mathrm{hr}$ & $25 \%$ \\
\hline \multirow[t]{3}{*}{ NOx } & $50 \%$ & $0,16 \mathrm{Kg} / \mathrm{hr}$ & $0,15 \mathrm{Kg} / \mathrm{hr}$ & $6,3 \%$ \\
\hline & $75 \%$ & $0,23 \mathrm{Kg} / \mathrm{hr}$ & $0,22 \mathrm{Kg} / \mathrm{hr}$ & $4,4 \%$ \\
\hline & $100 \%$ & $0,31 \mathrm{Kg} / \mathrm{hr}$ & $0,29 \mathrm{Kg} / \mathrm{hr}$ & $6,5 \%$ \\
\hline
\end{tabular}

VSDG systems that use power electronics also can control the active and reactive power supplied to the electrical network [31]. Another advantage is reducing the dynamic stress of the mechanical parts, implying less maintenance and increased engine life [32]. Finally, VSDGs can operate for extended periods at low rotation speed to withstand lower loads [33].

VSDGs adapt more quickly to the variable conditions of the electrical network, provide better controllability, effective damping of active power fluctuations, and minimize harmonic injection, facilitating integration into weak networks [34].

Many studies are conducted to improve the efficiency of Gensets operating at variable speed. Several solutions are proposed to relate the rotation of the diesel engine with the mechanical torque required by the generator. Some methods are focused on the treatment of electrical output, while others are based on mechanical conversion to synchronize the engine speed with the variable electrical charge profile.

\section{Variable Speed Diesel Generator Technologies}

VSDGs have many advantages over FSDGs systems, as discussed in the previous section. Among these advantages are the more significant operational flexibility that adapts the DEG rotation to the electrical load and reduces fuel consumption. This characteristic makes VSDGs widely used in regions where the electric grid is weak or isolated, without connection to the electric grid, especially 
in hybrid systems that combine DEG with wind or solar systems [35, 36]. This section presents the characteristics of the latest and most relevant technologies used by VSDGs, particularly electrical and mechanical approaches that allow the operation of variable speed of the DE depending on load variation.

Among the technologies presented, the most traditional ones use power electronics to correct the frequency and regulate the output voltage. We also present an electromechanical and a mechanical solution for the speed variation of the DEG according to load variation.

\subsection{Solutions Based on Power Electronics}

In variable speed systems based on power electronics, the generator is connected to the network through an ac/dc/ac converter, also called a frequency converter, which decouples the frequency of the network and the frequency of the generator, allowing the control of the rotation speed of the generator on a broader range $[35,36]$. Thus, the generator connected to the electric grid enables the decoupled control of active and reactive power, the effective damping of power fluctuations, the operation with maximum energy efficiency, and the minimization of the problems of power quality (dependent on the generator technology to be used), facilitating its integration into weak networks.

These variable speed systems can be equipped with wound rotor induction generators or synchronous generators.

\subsubsection{Diesel-Driven Wound-Rotor Induction Generator}

The most used generators in DEG assemblies are wound-rotor induction generators [33]. The induction machine has a structural symmetry with three-phase windings in stator and rotor. In wound rotor generators, rotor windings are made with copper wires, like the stator winding. This construction allows the connection of the rotor terminals by passive elements or external sources, which requires constructing a set of three collector rings and brushes that will enable the electrical connection between the rotating winding and the static terminal connections [37].

It is necessary to monitor the voltage amplitude and frequency deviation in variable speed applications. The machine stator can directly connect to the network for grid-connected installations that dictate the frequency and voltage [38]. For isolated installations without connection to the power grid, control strategies should be used to keep these parameters within the operational limits to ensure the quality of the supplied electricity. The control strategy is implemented considering rotor speed variation and load fluctuations $[39,40]$.

Generation systems using DEG, and the wound rotor induction generator have a separate exciter system for voltage control and a speed regulator for frequency control. The doubly excited generator allows frequency and voltage control, which are kept constant despite load fluctuations, through adjusting the current controller parameters.

In isolated systems, the induction generator rotor can be connected to an inverter with a battery bank, and its stator connected to a load and a capacitor bank. It also provides a magnetization current for the induction generator and controls the output voltage amplitude [41, 42].

Voltage and frequency control is achieved through the inverter connected to the induction generator rotor, Figure 6 . This equipment is responsible for stabilizing the voltage when the rotor speed varies according to the fluctuation of the load and regulating the frequency, controlling the 
electrical angle of the rotor. The inverter and battery bank are also used for starting the engine [ 43 , 44].

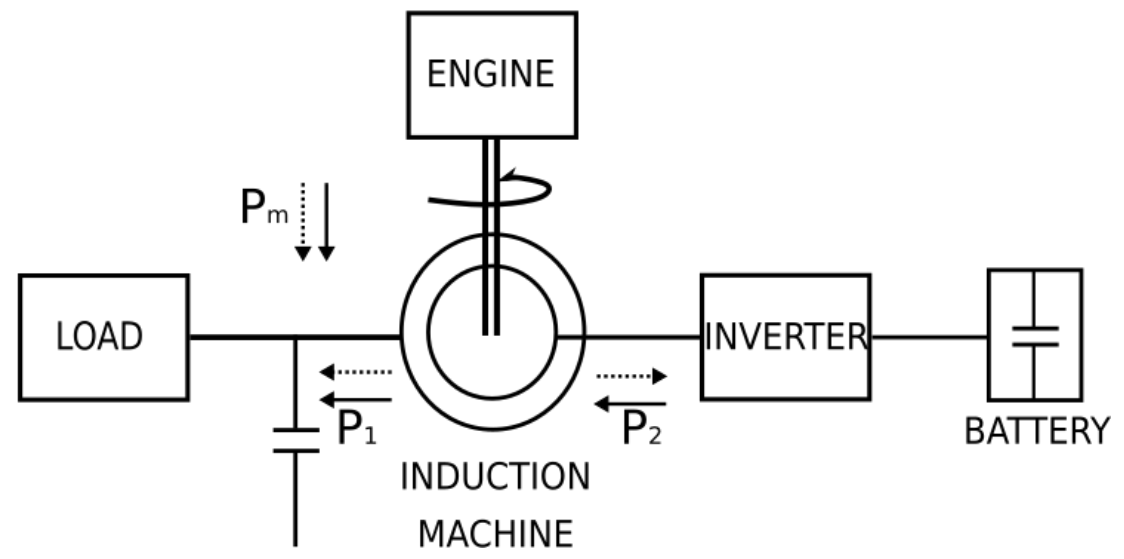

Figure 6 Wound rotor induction generator [44].

A disadvantage of this configuration is its slow dynamic response that does not support sudden significant changes in the electrical system. It is more efficient when combined with other renewable energy sources, such as hybrid systems that combine wind and photovoltaic with the diesel generator set.

Diesel-Driven Doubly-Fed Induction Generator (DFIG). The Doubly-Fed Induction Generator is a particular operation of the wound rotor induction generator having independent feeding on stator and rotor windings. When the induction generator operates connected to the power grid, we can use a Doubly Fed Induction Generator (DFIG), one of the most competitive technologies for generation systems operating at variable speed. The DFIG technology has been extensively studied and is widely used. However, its operation is greatly affected by disturbances in the electrical network. Therefore, many studies dealings with system modeling to develop complex control strategies are available in the literature.

The standard configuration of the electrical generation system using a doubly-fed induction machine, using the slipping power, is shown in Figure 7. The machine stator is connected directly to the power grid in this system. The rotor circuit is powered by two PWM converters and a transformer responsible for the adequacy of the voltage level.

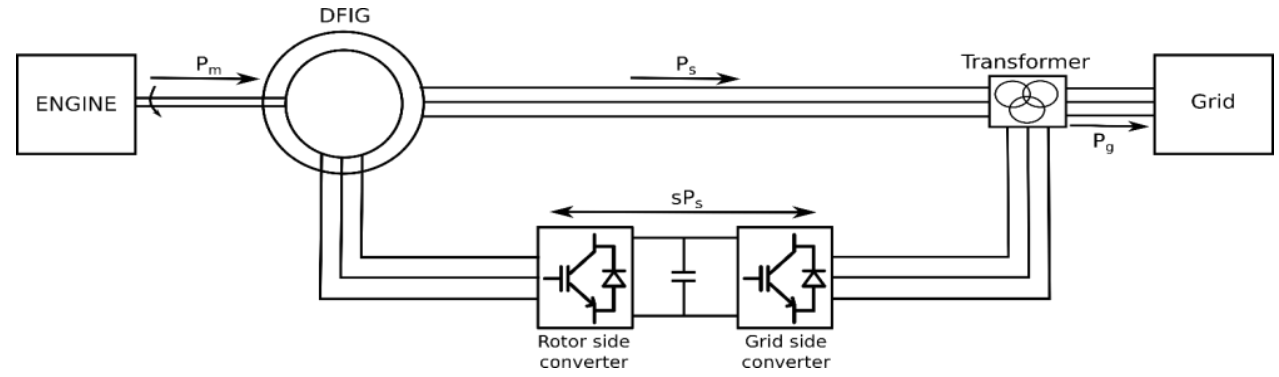

Figure 7 Diesel-driven doubly-fed induction generator. 
This setting enables the doubly-fed induction generator to work by varying the speed within the operating limits, depending on the load fluctuation, in subsynchronous and super-synchronous rotation. The power to the network is made with the machine working below, above, and even at the synchronous speed [45]. The power flow can be established both from the induction generator rotor to the power grid and in the reverse direction. The converters must operate respectively in the rectification to transfer electrical power from the rotor circuit to the power supply [44].

A vector control strategy is adopted to manage the rotor's injection/consumption of power, generating independent PWM pulses for the IGBTs (Insulated Gate Bipolar Transistors). The gridside converter controls the voltage on the DC bus and supplies reactive power to the rotor. The machine-side converter controls the rotor's active power and reactive stator power, using an orientation strategy for the quantities according to the stator flow, ensuring a decoupling between the active and reactive power control channels [46].

This setting allows power converters with a power rating equal to a fraction of the generator power. This feature will enable lower cost but simultaneously limits the generator's speed range according to the converter's rated power [47]. The sizing of the converters should be done considering that speed varies according to system load. Traditionally, the converter power is chosen around $30 \%$ of the generator's rated capacity. The operation of the generation system above or below the limits results in unwanted harmonics [44].

Another disadvantage of this configuration is its high sensitivity to voltage variations in the electrical network, such as voltage sags. One way to improve the supportability to voltage sags and protect the DFIG, highly discussed in the literature, is using the crowbar device $[48,49]$. This device is a circuit designed to protect the rotor converter from overcurrent, which occurs from voltage transients in the stator [50]. It can be formed by a three-phase resistor bank or by a thyristor rectifier bridge and a load resistor $[46,51]$.

\subsubsection{Diesel-Driven Permanent Magnet Synchronous Generator}

Synchronous generators are also used in VSDG systems. However, most applications of these generators with DEG use Permanent Magnet Synchronous Generator (PMSG). These generators are more efficient than conventional synchronous machines and simpler because they do not require external excitation. In addition, its rotor with permanent magnets eliminates Joule losses on the rotor, thus achieving higher efficiency levels [52].

Many studies propose different control strategies for these generator sets to improve the system's efficiency [53-64]. In these studies, the power flow extracted from the engine through the generator is controlled by the electronic power converter.

In [61], the applied power electronics converter is built based on the intermediate voltage of the $\mathrm{dc}$ link. The voltage of the variable frequency and amplitude generator is rectified and then converted into ac voltage. This concept is accomplished by applying several different rectifier and inverter topologies. The power converter controls the rectified current and thus adjusts the load torque produced by the generator.

In [60], the generator engine group consists of an internal combustion engine, a synchronous generator with permanent magnets, a battery bank, and static converters, as shown in Figure 8 . The topology is composed of a back-to-back converter, a two-way interleaved boost converter 
connected to a battery bank, a dc bus, and the synchronous permanent magnet generator (PMSG) [61].

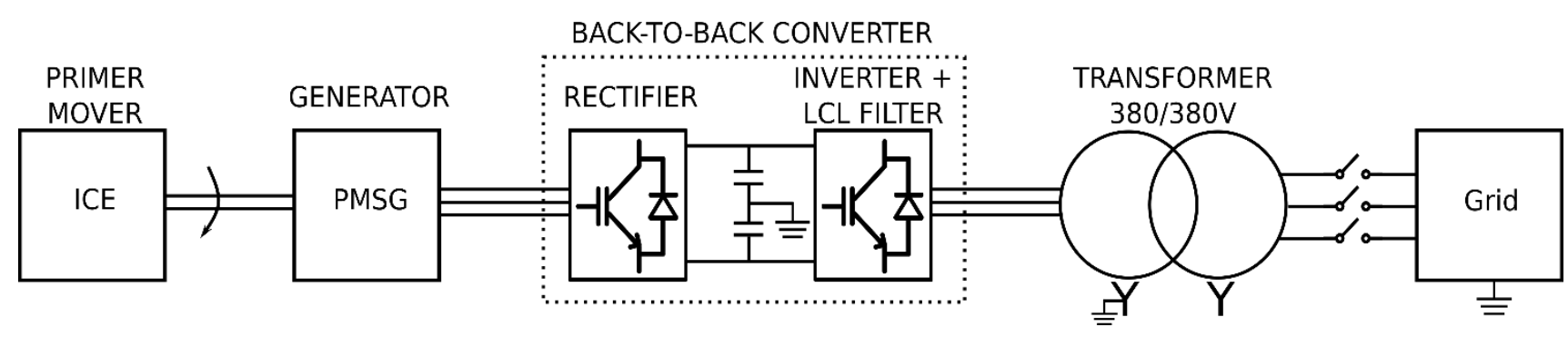

Figure 8 Genset with PMSG [44].

The rectifier controls the synchronous generator currents. All electricity generated is transferred to the DC bus, where its voltage is regulated by the buck-boost converter, storing or removing energy from the battery bank. The inverter uses the energy in the dc bus to supply the load. The buck-boost converter is responsible for controlling the charge/discharge current of the battery bank and for regulating the dc bus voltage from the battery bank current. The batteries operate as an energy buffer between the generator and the output load with this arrangement. Thus, unnecessary torque/speed transients are avoided at the engine, implying greater fuel consumption [60]. The rotation of the internal combustion engine, directly coupled with the synchronous generator, is controlled through a closed-loop injection system to follow an optimal speed reference.

In [52], the problem of slowing the dynamic behavior of the engine in the face of sudden power variations is compensated by the inclusion of supercapacitors in the dc bus, also reducing the emission of pollutants and fuel consumption.

Since all power energy in PMSGs is generated at a variable frequency, proportional to the mechanical speed of the DEG, a full-power converter (FPC) is required. Although these components are more expensive and present more significant electrical losses than the partial converters used in a DFIG, it is noteworthy that the use of an FPC provides a complete decoupling with the network. Thus, they ensure lower sensitivity of the generation system to disturbances from the external network to the system. On the other hand, a disadvantage of the PMSG-based generation systems is the cost of manufacturing the synchronous machine. This cost is high due to the complexity of machine construction that keeps the air gap between stator and rotor small, even with machines of several meters in diameter. It is also because rare earth magnet prices have significant volatility. Some elements are highly susceptible to corrosion or sensitive to heat, with the possibility of permanent loss of magnetic field or polarity reversal [61].

\subsection{Rotating-Stator Generator}

It is a new electrical technology patented in Canada, the United States, and Australia known as Genset-Synchro. This technology uses an electromechanical solution for operating at variable speed, without power converters.

The generation system consists of a diesel engine, a synchronous generator, and an auxiliary compensating motor. The difference in this technology is that the synchronous machine stator is not stationary. Therefore, the structure of this machine is modified. First, bearings are installed in 
its outer layer, between the stator and the generator housing, allowing the free rotation of the stator about the rotor [63].

The compensating motor is installed on a casing fixed to the synchronous generator housing. The motor's output shaft is aligned in parallel with the stator shaft [64]. The shafts of the compensating motor and the stator are connected via a toothed belt and pulleys. The relative speed of the system will be the combination of the rotations of the rotor and the stator. The stator can rotate in the same direction as the rotor or in the opposite direction. The goal is that the relative speed is always constant and equal to the synchronous speed. Figure 9 shows a diagram representation of this technology, while Figure 10 shows the system's main components.

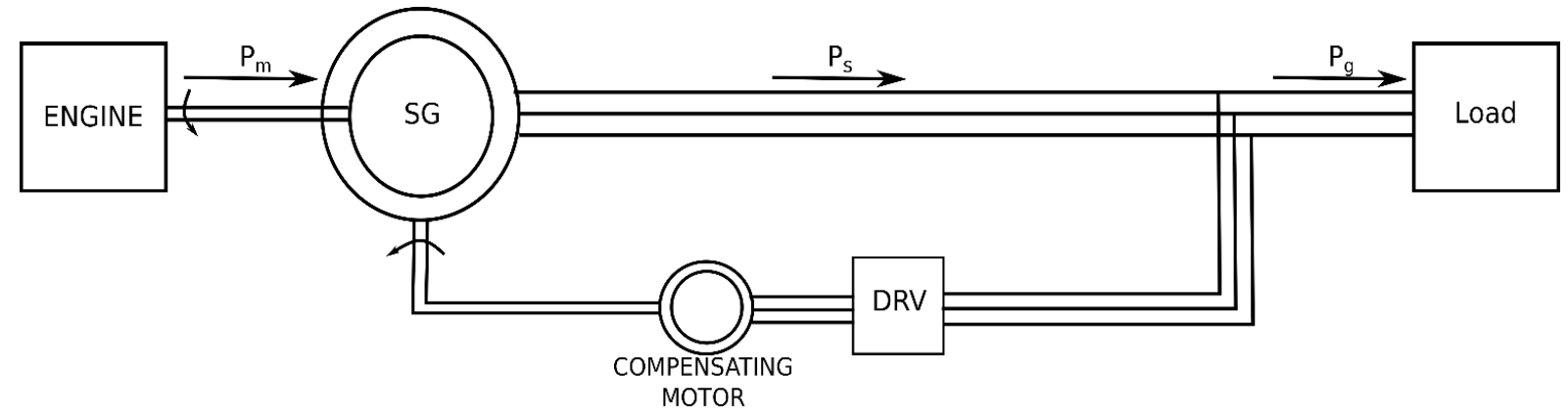

Figure 9 Rotating-Stator Mode technology [47].

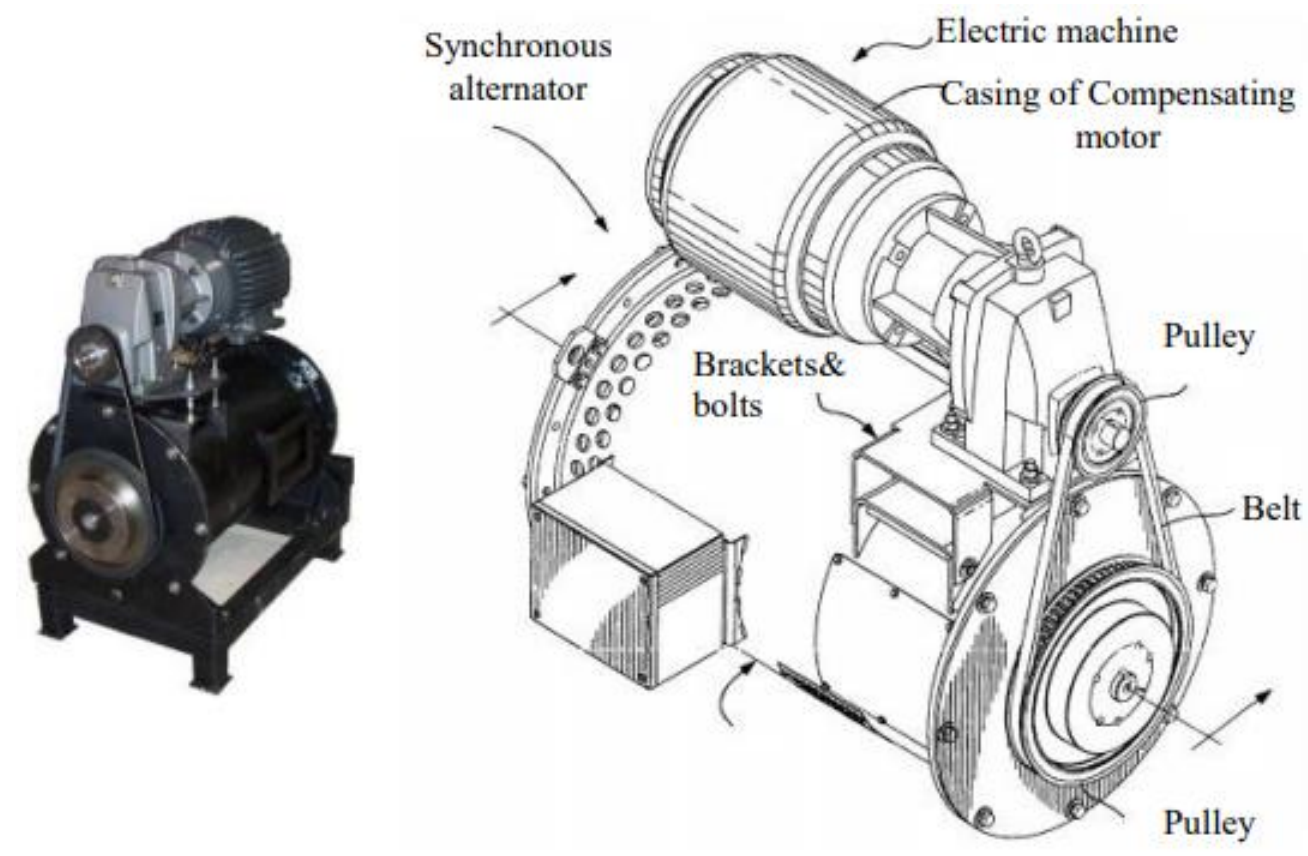

Figure 10 The concept and main components of the rotating stator generator.

During a low load operation, the rotor, fixed to the diesel engine (DE) shaft, can slow down to increase efficiency. This is because the power generator reaches synchronous speed by turning the stator in the opposite direction to the rotor. This feature allows the DE to operate within its optimum speed range while there is a considerable change in electrical load [65].

Up to $15 \%$ of the energy generated by the synchronous generator is used to power the compensating motor, so the generator itself provides its energy. No other modifications are made 
to the synchronous machine rotor. The windings of the stator also remain the same [1]. Power converters are used to control the Genset-Synchro compensator motor. As this motor has a power equal to a small fraction of the permanent magnet synchronous generator (PMSG), the costs with the power electronics are less, as are the negative impacts of the power converters on the system, such as the presence of harmonics due to the switching thyristors [65]. Figure 11 shows a diagram representation of this control system.

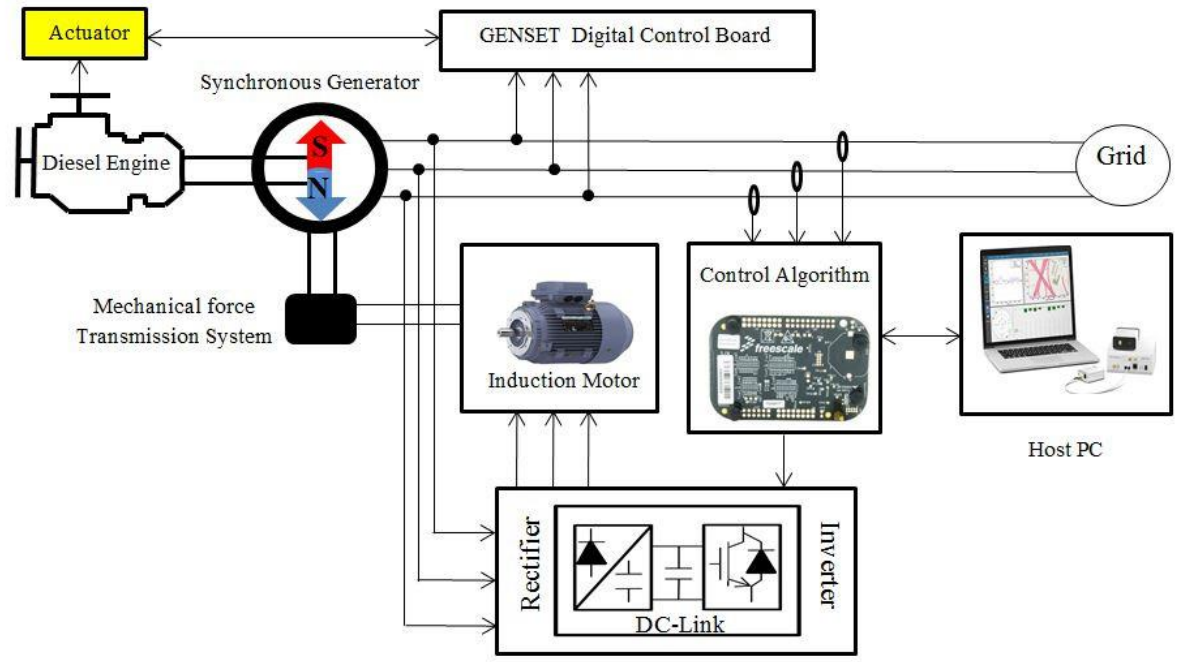

Figure 11 Rotating-Stator Mode technology with automatic control system [48].

The main advantage is that this solution can be applied in isolated locations in the existing generator without modifying the diesel engine block. Studies $[1,3,64-66]$ show that the GensetSynchro system saves up to $15 \%$ when the applied load is below $40 \%$ of the rated power and an average reduction of $7 \%$ of pollutant emissions. The disadvantage of this technology is the presence of brushes in the synchronous generator that require higher maintenance frequency. In addition, its maximum power is limited to $85 \%$ due to the compensation motor that drives the stator [1, 3 , 64-66].

\subsection{Continuously Variable Transmission (CVT)}

The application of CVT to variable speed generators emerges as an economical alternative to electronic power systems for small and medium-sized equipment. Moreover, incorporating squirrel cage induction generators, known for their low cost and high reliability, makes this configuration even more economically attractive.

In the continuously variable transmission system, CVT, within a restricted range, a great number of transmission interfaces is possible [67]. This technology was initially applied to car transmission systems to benefit the smooth transition between the relations, reducing the fatigue of mechanical components and increasing the engine performance. There are various configurations of the CVT according to the type of application, the torque, and the speed. They are generally classified according to the transmission elements used as toroids, spheres, belts, and chains.

The application of CVT in electric power generating systems is motivated by the increase in the rotor speed range, making it possible to operate at a speed of greater efficiency for the DEG according to load variation without changing the generator's synchronous speed. As a result, 
Gensets connected to the grid that use CVT can have up to $27 \%$ fuel economy [68]. This characteristic enhances CVT application in high-reliability generators such as permanent magnet synchronous and induction asynchronous, with cage rotor, presenting benefits such as reduced maintenance costs and power electronics [69]. Figure 12 indicates the Genset scheme developed with a proposed CVT system. The variation of the DE speed depends on CVT's flexibility and electrical demand.

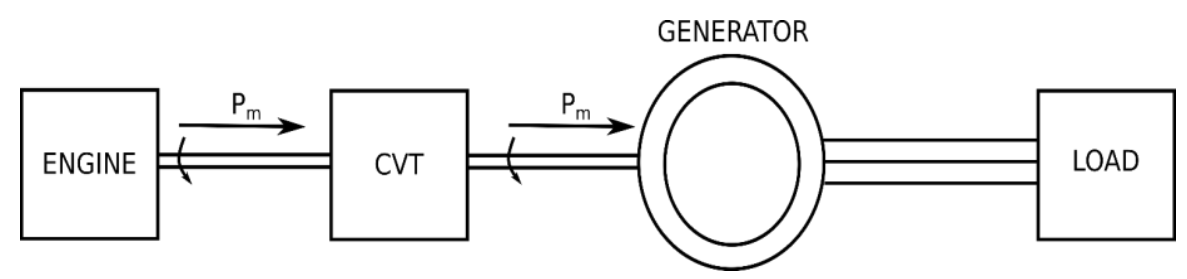

Figure 12 Diagram of powertrain using CVT technology.

As this is a mechanical solution, this technology does not include control strategies that improve the quality of the electricity produced. However, since it does not use power electronics, it also does not inject harmonics into the system.

This technology's advantages are a low complexity in the control system and a low initial investment cost [70]. This feature makes this technology ideal for isolated systems that provide power to small communities or when low load represents a large portion of the machine's operating time. It is also used in applications connected to the power grid to regulate frequency and increase stability [68].

\section{Comparison of VSDG Technologies According to Possible Applications}

As discussed in the previous section, each VSDG technology has advantages and disadvantages. One cannot generalize by choosing one of them as the best overall diesel generator technology operating at variable speed. The different applications that use VSDG should be considered according to the characteristics of each specific system.

Among the main characteristics to be considered for selecting the most appropriate VSDG technology, it is necessary to analyze whether the diesel engine generator is connected to the power grid, works isolated, or is part of a hybrid system combined with renewable energy sources. In addition, it is also essential to know the load characteristics, such as the speed variation, the operating levels, the peak and low load periods, for example.

Most of the references used for the development of this study deal with autonomous systems. The diagram below shows which references deal with autonomous systems and with systems connected to the network (Figure 13). 


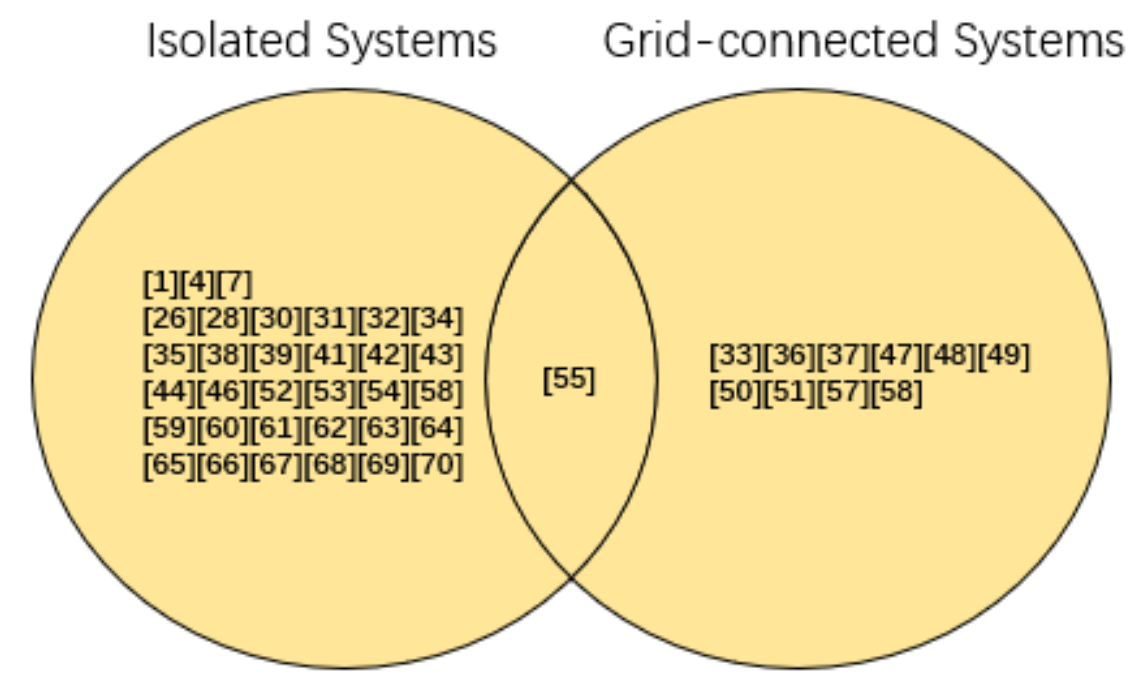

Figure 13 Classification of references according to connection to the energy network.

The power quality supplied to the consumer is an important feature that the managers of an electrical system closely monitor. Limits on the voltage and frequency values are imposed to ensure the system's proper functioning and the power supply quality. An energy conversion system using DEG can be a generator of disturbances in the power grid, causing power quality phenomena such as voltage fluctuations (flicker) and harmonic distortion. It can also suffer the effect of disturbances existing in the electrical network. Among these, the impact of momentary voltage sags in generation systems stands out [49].

Harmonic distortions are a problem for technologies that use frequency converters in their switching operation. For example, in DFIGs, which use converters feeding the rotor circuit, only a small portion of the power (approximately $1 / 3$ of the total power of the shaft) passes through the converters $[48,49]$. In contrast, in the PMSGs, which use stator converters, all power passes through the converters [46]. Thus, in the technology that uses converters at full power, the impact caused by harmonic distortions is greater for the same generated power.

The inverter control using pulse width modulation has as main objective to minimize distortions at low frequencies. The use of PWM makes the most significant distortion frequencies become located in the region of multiples of the switching frequency, thus reducing the costs with filters, which may have higher cutting frequencies. Usually, L series, LC, or LCL series-parallel filters or filters tuned to frequencies near the switching frequency are used. These filters are essential to minimize harmonics' penetration in the switching frequency, and its multiples in the electrical network to values allowed for the power supply. Despite this characteristic, VSDG technologies that use power converters are the most widespread solutions today. They are present in applications connected to the grid $[48,49]$ or isolated regions [46, 52-62]. These technologies are widely studied, and many projects develop control strategies to ensure the best efficiency of these systems, with the lowest fuel consumption.

A momentary voltage sag can be caused by short circuits, overloads, and the start of large motors. The operators of electrical systems consider a criterion for connecting a generation system its ride-through fault capability (RTF), that is, the ability to remain connected to the grid during 
momentary voltage sags at the connection point. DFIGs are very sensitive to disturbances in the power grid. Thus, many studies define control strategies to solve this problem [49].

Another critical aspect to consider is the value of the project's initial investment. For small communities in isolated regions, where load fluctuation is small, the most feasible solution would be to use a generation system that reliably provides electricity with the lowest control complexity and a low initial cost. In this case, the CVT and the Rotating-Stator Mode (RSM) for the Diesel Generator would be the most suitable technologies [1, 7, 66-69]. Compared to others who use power electronics, the disadvantage of these two technologies is higher maintenance rates. However, the RSM, a newer technology, has proven to be a good alternative for long-term applications [66].

For systems that operate isolated with large fluctuations of the electric loads, it is necessary to use a compensation system to avoid harmonic pollution. In such cases, the use of PMSG equipped with supercapacitors as described in [52] is recommended. This system, however, requires a high initial investment [52]. Wound rotor induction generators are not suitable in isolated systems that present large electrical load fluctuations. As the inverter directly controls the excitation system, with limited capacity, sudden changes at the stator terminals can ruin the rotor winding [44, 45]. Therefore, these generators are best for systems with low load variation or in applications combined with other renewable energy sources $[25,44]$.

The diagram below classifies the references used in the development of this study according to the primary source of energy used to generate electricity (Figure 14). As this work deals with technologies applied to the diesel engine, most references use diesel as a primary source. Still, hybrid generation systems have been a widely used alternative to combine diesel's high reliability and stability with renewable energy sources such as wind and photovoltaic.

\section{Primary Source}

- Diesel \& Battery

- Diesel

Diesel \& Wind

- Wind

- Diesel \& PV

- Diesel \& PV \& Wind

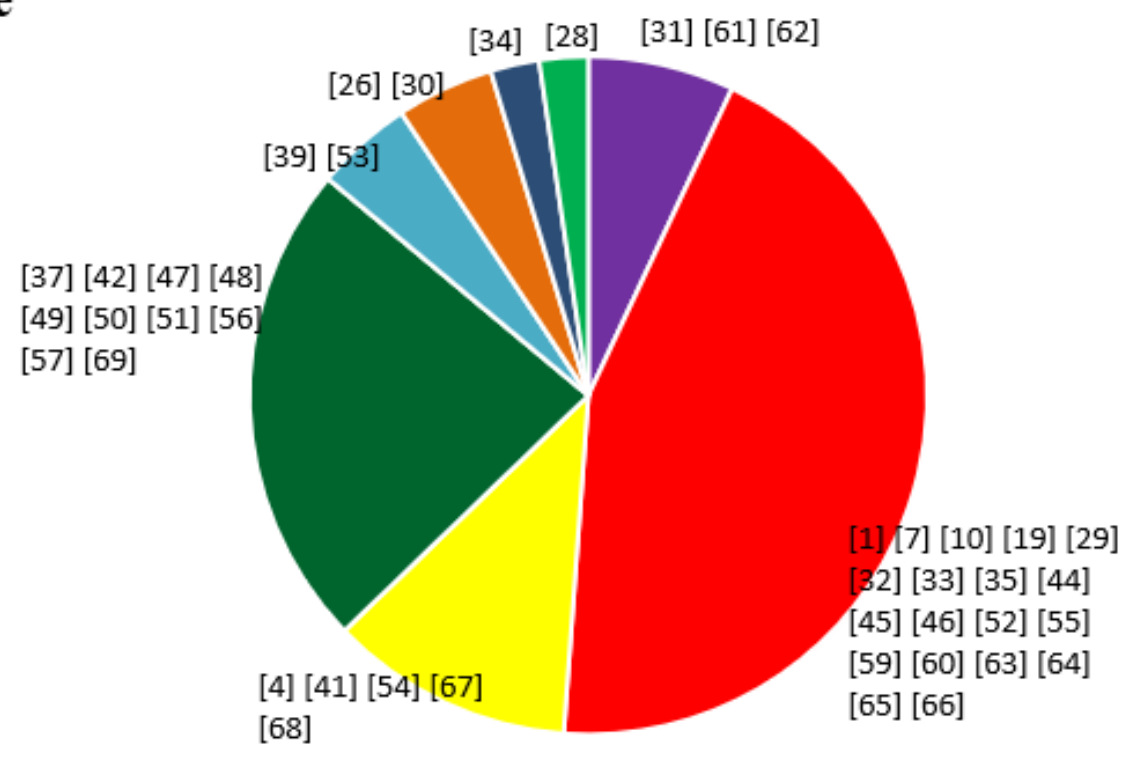

Figure 14 Classification of references according to the primary source of energy.

Table 2 summarizes the main aspects discussed in this paper, highlighting the technologies studies, the most suitable application scenario, the advantages, and disadvantages. 
Table 2 Most suitable application scenario, advantages, and disadvantages of the selected technologies.

\begin{tabular}{|c|c|c|c|}
\hline Technologies & $\begin{array}{l}\text { Most Suitable } \\
\text { Application Scenario }\end{array}$ & Advantages & Disadvantages \\
\hline $\begin{array}{l}\text { Wound-Rotor } \\
\text { Induction Generator }\end{array}$ & $\begin{array}{l}\text { For systems that } \\
\text { operate isolated with } \\
\text { low load variation. }\end{array}$ & $\begin{array}{l}\text { Technology is well } \\
\text { known and } \\
\text { consolidated in the } \\
\text { market. } \\
\text { Low cost, simple } \\
\text { construction, and easy } \\
\text { maintenance } \\
\text { Requires a low power } \\
\text { converter. }\end{array}$ & $\begin{array}{l}\text { Slow dynamic } \\
\text { response which } \\
\text { cannot withstand } \\
\text { sudden changes in the } \\
\text { electrical system. } \\
\text { Harmonic distortion. }\end{array}$ \\
\hline $\begin{array}{l}\text { Doubly-Fed Induction } \\
\text { Generator (DFIG) }\end{array}$ & $\begin{array}{l}\text { For systems } \\
\text { connected to the } \\
\text { power grid. }\end{array}$ & $\begin{array}{l}\text { Technology is well } \\
\text { known and } \\
\text { consolidated in the } \\
\text { market. } \\
\text { Can operate like a } \\
\text { synchronous } \\
\text { generator at variable } \\
\text { speed } \\
\text { Fewer harmonics } \\
\text { because control is in } \\
\text { the rotor while stator } \\
\text { is directly connected } \\
\text { to the grid } \\
\text { Easier } \\
\text { torque control using } \\
\text { rotor current control } \\
\text { Requires a low power } \\
\text { converter. }\end{array}$ & $\begin{array}{l}\text { DFIGs are very } \\
\text { sensitive to } \\
\text { disturbances in the } \\
\text { power grid. }\end{array}$ \\
\hline $\begin{array}{l}\text { Permanent Magnet } \\
\text { Synchronous } \\
\text { Generator }\end{array}$ & $\begin{array}{l}\text { For systems that } \\
\text { operate isolated with } \\
\text { large fluctuations of } \\
\text { the electric loads. }\end{array}$ & $\begin{array}{l}\text { Technology is well } \\
\text { known and } \\
\text { consolidated in the } \\
\text { market. } \\
\text { It can produce utility- } \\
\text { type power without } \\
\text { and external power } \\
\text { grid }\end{array}$ & $\begin{array}{l}\text { The impact caused by } \\
\text { harmonic distortions } \\
\text { is more significant for } \\
\text { the same generated } \\
\text { power in DFIG. } \\
\text { Magnet's } \\
\text { characteristics tend to } \\
\text { change over time }\end{array}$ \\
\hline
\end{tabular}


Rotating-Stator Mode

Continuously Variable Transmission (CVT)
For small communities located in isolated regions, where load fluctuation is small.
For small communities located in isolated regions, where load fluctuation is small.
Demagnetization caused by too high temperatures or too high currents

Low initial investment of the project.

It can be applied in The presence of isolated places on the brushes in the existing generator, synchronous without the need to generator which modify the diesel require a higher engine block. maintenance Electronic converter is frequency not required The maximum power If the compensating is limited to $85 \%$ due motor fails, the to the supply of the generator can compensating motor. continue to operate as FSDG

Cannot be applied on the systems over 200 $\mathrm{kW}$. gear ratio.

Very high fuel saving (up to $27 \%$ )
Must be replaced in case of failure.

Restricted space in the event of a retrofit

Table 3 provides an overview of the main studies from the sample considered. The references are classified according to the technology studied in each of them.

Table 3 Classification of references according to the technology studied in each of them.

\begin{tabular}{ll}
\hline Technologies & References \\
\hline Fixed Speed Generator & {$[24,26-28,31,32,34,35,40,46,48]$} \\
Wound-Rotor Induction Generator & {$[34,35,41-45]$} \\
DFIG & {$[26,33,36,37,47-51]$} \\
PMSG with Power Electronics & {$[4,19,28,34,46,52-62]$} \\
PMSG with Rotating Stator Mode & {$[1,7,63-66]$} \\
\hline
\end{tabular}




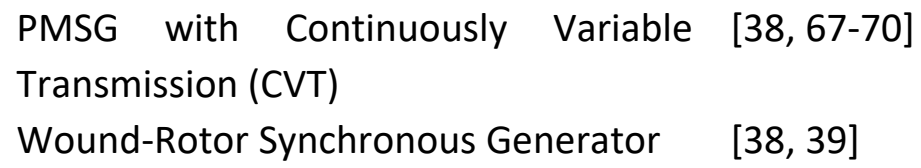

\section{Conclusion}

For most of their energy requirements, the more significant part of remote communities, small islands, and means of transport (rail and ship) worldwide rely on imported fossil fuels. Therefore, the economic cost of energy is very high not only due to the inherent fuel cost but also to transportation and maintenance costs. In addition, the race against climate change, the reduction of greenhouse gas emissions, and the decline of the fossil oil reserve accompanied by unstable prices have led the electric energy market to be more open, enabling for more flexible distributed power systems to be developed such as VSDG.

One solution for saving fuel in a diesel generator is to allow the engine to vary according to the electrical load at variable speeds. Furthermore, when compared to FSDG-powered systems, VSDGpowered systems result in lower fuel consumption and, as a result, lower gas emissions and harmful particles. In this paper, different VSDG have been presented and compared, including PMSG with power electronic converter, Wound-rotor induction generator, PMSG with the rotating stator, Wound rotor synchronous generator, and PMSG with a continuous variable transmission. It has been found that the use of electronic converters remains the most common technology despite the fact it is considered a significant source of harmonics. According to Table 2, each of these technologies has advantages and disadvantages. It cannot be concluded that one among them is the best VSDG technology. For each different type of application, a technology would be the most indicated. The choice depends on factors such as cost of the initial investment, load fluctuations, slow or sudden, and small or large, the procedure adopted for operating the system. It also depends on whether it is connected to the power grid or works isolated, the complexity of the control system, and the frequency of machine maintenance.

\section{Author Suggestions for Future Work}

In the next step, the author will model an $800 \mathrm{hp}$ diesel engine driving a rotary stator generator to study and analyse the quality of the signals (voltage, current, frequency, and harmonics) when put under a variable load in an isolated community. An analysis of fuel consumption and GHG emissions will also be performed. Furthermore, the authors compare different systems in terms of investment and profit for reference to select their appropriate Gensets.

\section{Author Contributions}

R. Barbosa organized the structure of the paper and contributed significantly to the writing of the paper. A. llinca supervised the work, and M. Issa prepared and revised the paper. S. Silva gave the suggestions and supervision. All authors discussed the structure and contributed to the final paper. 


\section{Competing Interests}

The authors declare that they have no known competing financial interests or personal relationships that could have appeared to influence the work reported in this paper.

\section{References}

1. Issa M, Fiset J, Mobarra M, Ibrahim H, Ilinca A. Optimizing the performance of a 500kW diesel generator: Impact of the Eo-synchro concept on fuel consumption and greenhouse gases. Power Eng. 2018; 23: 22-31.

2. Issa $M$, Ibrahim $H$, Lepage $R$, Ilinca $A$. A review and comparison on recent optimization methodologies for diesel engines and diesel power generators. J Power Energy Eng. 2019; 7: 3156.

3. Issa M, Ibrahim H, llinca A, Hayyani MY. A review and economic analysis of different emission reduction techniques for marine diesel engines. Open J Mar Sci. 2019; 9: 148-171.

4. Chen Z, Hu Y. A hybrid generation system using variable speed wind turbines and diesel units. Proceedings of the 29th Annual Conference of the IEEE Industrial Electronics Society; 2003 November 2-6; Roanoke, VA, USA. Piscataway Township: Institute of Electrical and Electronics Engineers.

5. Issa $M$, Ibrahim $H$, Hosni $H$, Ilinca $A$, Rezkallah $M$. Effects of low charge and environmental conditions on diesel generators operation. Eng. 2020; 1: 137-152.

6. Issa M. Operational, ecological and energy optimization of diesel generators. Rimouski: University of Quebec at Rimouski, Department of Mathematics, Computer Science and Engineering; 2020. pp.252.

7. Issa M, Fiset J, Ibrahim H, llinca A. Eco-friendly selection of diesel generator based on gensetsynchro technology for off-grid remote area application in the north of Quebec. Energy Power Eng. 2019; 11: 232-247.

8. Ibrahim H, Issa M, Lepage R, llinca A, Perron J. Supercharging of diesel engine with compressed air: Experimental investigation on greenhouse gases and performance for a hybrid wind-diesel system. Smart Grid Renew Energ. 2019; 10: 213-236.

9. Ağbulut Ü, Karagöz M, Sarıdemir S, Öztürk A. Impact of various metal-oxide based nanoparticles and biodiesel blends on the combustion, performance, emission, vibration and noise characteristics of a Cl engine. Fuel. 2020; 270: 117521.

10. Espadafor FJ, Villanueva JB, García MT. Analysis of a diesel generator crankshaft failure. Eng Fail Anal. 2009; 16: 2333-2341.

11. Issa $M$, Beaulac $P$, Ibrahim $H$, llinca $A$. Marinization of a two-stage mixed structured packing scrubber for sox abatement and $\mathrm{CO}_{2}$ capture. Int J Adv Res. 2019; 7: 73-82.

12. Ağbulut Ü, Gürel $A E$, Sarıdemir S. Experimental investigation and prediction of performance and emission responses of a $\mathrm{Cl}$ engine fuelled with different metal-oxide based nanoparticles-diesel blends using different machine learning algorithms. Energy. 2021; 215: 119076.

13. Ağbulut Ü, Sarıdemir S, Albayrak S. Experimental investigation of combustion, performance and emission characteristics of a diesel engine fuelled with diesel-biodiesel-alcohol blends. J Braz Soc Mech Sci. 2019; 41: 389.

14. Ağbulut Ü, Sarıdemir S. A general view to converting fossil fuels to cleaner energy source by adding nanoparticles. Int J Ambient Energy. 2021; 42: 1569-1574. 
15. Abbas $T$, Issa $M$, Ilinca A. Biomass cogeneration technologies: A review. J Sustain Bioeng Syst. 2020; 10: 1-15.

16. Abbas $T$, Issa $M$, llinca A, El-Ali A. Biomass combined heat and power generation for Anticosti Island: A case study. J Power Energy Eng. 2020; 8: 64-87.

17. Ağbulut $U ̈$, Bakir $H$. The investigation on economic and ecological impacts of tendency to electric vehicles instead of internal combustion engines. Düzce Univ J Sci Technol. 2019; 7: 25-36.

18. Fayad A, Ibrahim H, Ilinca A, Sattarpanah Karganroudi S, Issa M. Energy recovering using regenerative braking in diesel-electric passenger trains: Economical and technical analysis of fuel savings and ghg emission reductions. Energies. 2022; 15: 37.

19. Dengler P, Geimer M, Zahoransky R. Potential of reduced fuel consumption of diesel-electric APUs at variable speed in mobile applications. SAE Tech Pap. 2011. Doi: 10.4271/2011-24-0075.

20. Ağbulut Ü, Sarıdemir S, Karagöz M. Experimental investigation of fusel oil (isoamyl alcohol) and diesel blends in a $\mathrm{Cl}$ engine. Fuel. 2020; 267: 117042.

21. Karagoz M, Uysal C, Agbulut U, Saridemir S. Exergetic and exergoeconomic analyses of a $\mathrm{Cl}$ engine fueled with diesel-biodiesel blends containing various metal-oxide nanoparticles. Energy. 2021; 214: 118830.

22. Karagöz M, Ağbulut Ü, Sarıdemir S. Waste to energy: Production of waste tire pyrolysis oil and comprehensive analysis of its usability in diesel engines. Fuel. 2020; 275: 117844.

23. Issa M, Ilinca A. Petrodiesel and biodiesel fuels for marine applications. In: Petrodiesel Fuels. Boca Raton: CRC Press; 2021. pp.1015-1033.

24. Bram $R$, Johan $D$, Jan $C$. Variable speed genset with full rated power converter using readily available industrial products. Proceedings of the 16th European Conference on Power Electronics and Applications; 2014 August 26-28; Lappeenranta, Finland. Piscataway Township: Institute of Electrical and Electronics Engineers.

25. Al-suod MM, Alexander UO, Olga DI. Optimization of the structure of diesel-generator units of ship power system. Int J Adv Comput Res. 2015; 5: 68-74.

26. Nayar CV. High renewable energy penetration diesel generator systems. London: IntechOpen Access Publisher; 2012.

27. Barakat A, Tnani S, Champenois G, Mouni E. Analysis of synchronous machine modeling for simulation and industrial applications. Simul Model Pract Theory. 2010; 18: 1382-1396.

28. Hamilton J, Negnevitsky M, Wang X. The potential of variable speed diesel application in increasing renewable energy source penetration. Energy Procedia. 2019; 160: 558-565.

29. Shirneshan A, Almassi M, Ghobadian B, Borghei AM, Najafi G. Brake specific fuel consumption of diesel engine by using biodiesel from waste cooking oil. World Sci J. 2013; 1: 45-52.

30. Hamilton J, Negnevitsky M, Wang X. Low load diesel perceptions and practices within remote area power systems. Proceedings of the 2015 International Symposium on Smart Electric Distribution Systems and Technologies; 2015 September 8-11; Vienna, Austria. Piscataway Township: Institute of Electrical and Electronics Engineers.

31. Guo L, Fu X, Li X, Wang C. Coordinated control of battery storage system and diesel generators in $A C$ island microgrid. Proceedings of the 7th International Power Electronics and Motion Control Conference; 2012 June 2-5; Harbin, China. Piscataway Township: Institute of Electrical and Electronics Engineers.

32. Ayodele TR, Ogunjuyigbe AS, Akinola OA. n-Split generator model: An approach to reducing fuel consumption, $\mathrm{LCC}, \mathrm{CO}_{2}$ emission and dump energy in a captive power environment. Sustain 
Prod Consum. 2017; 12: 193-205.

33. Wang DH, Nayar CV, Wang C. Modeling of stand-alone variable speed diesel generator using doubly-fed induction generator. Proceedings of the 2nd International Symposium on Power Electronics for Distributed Generation Systems; 2010 June 16-18; Hefei, China. Piscataway Township: Institute of Electrical and Electronics Engineers.

34. Manwell JF, Stein WA, Rogers A, McGowan JG. An investigation of variable speed operation of diesel generators in hybrid energy systems. Renew Energ. 1992; 2: 563-571.

35. Greig $M$, Wang J. Fuel consumption minimization of variable-speed wound rotor diesel generators. Proceedings of the 43rd Annual Conference of the IEEE Industrial Electronics Society; 2017 October 29-November 1; Beijing, China. Piscataway Township: Institute of Electrical and Electronics Engineers.

36. Tang $\mathrm{Y}, \mathrm{Xu} \mathrm{L}$. A flexible active and reactive power control strategy for a variable speed constant frequency generating system. IEEE Trans Power Electron. 1995; 10: 472-478.

37. Oliveira RG. Contribuição ao controle de um sistema de geração a velocidade variável utilizando gerador de indução duplamente excitado. Belo Horizonte: Universidade Federal de Minas Gerais; 2009.

38. Benhamed S, Ibrahim H, Belmokhtar K, Hosni H, llinca A, Rousse D, et al. Dynamic modeling of diesel generator based on electrical and mechanical aspects. Proceedings of the 2016 IEEE Electrical Power and Energy Conference; 2016 October 12-14; Ottawa, Canada. Piscataway Township: Institute of Electrical and Electronics Engineers.

39. Maritz J. Optimized energy management strategies for campus hybrid pv-diesel systems during utility load shedding events. Processes. 2019; 7: 430.

40. Krause PC, Wasynczuk O, Sudhoff SD. Analysis of electric machinery. New York: The Institute of Electrical and Electronics Engineers Inc.; 1995.

41. Pena R, Cardenas R, Proboste J, Clare J, Asher G. A hybrid topology for a variable speed winddiesel generation system using wound rotor induction machines. Proceedings of the 31st Annual Conference of IEEE Industrial Electronics Society; 2005 November 6-10; Raleigh, NC, USA. Piscataway Township: Institute of Electrical and Electronics Engineers.

42. Chaudhury AB. A novel sensor-less position and speed estimation scheme for wound rotor induction machine. Proceedings of the 2011 International Conference on Emerging Trends in Electrical and Computer Technology; 2011 March 23-24; Nagercoil, India. Piscataway Township: Institute of Electrical and Electronics Engineers.

43. Forchetti DG, Solsona JA, García GO, Valla MI. A control strategy for stand-alone wound rotor induction machine. Electr Power Syst Res. 2007; 77: 163-169.

44. Kawabata Y, Oka T, Ejiogu E, Kawabata T. Variable speed constant frequency stand-alone power generator using wound-rotor induction machine. Proceedings of the 4th International Power Electronics and Motion Control Conference; 2004 August 14-16; Xi'an, China. Piscataway Township: Institute of Electrical and Electronics Engineers.

45. Kawabata Y, Morine Y, Oka T, Ejiogu EC, Kawabata T. New stand-alone power generating system using wound-rotor induction machine. Proceedings of the 4th IEEE International Conference on Power Electronics and Drive Systems; 2001 October 25; Denpasar, Indonesia. Piscataway Township: Institute of Electrical and Electronics Engineers.

46. Leuchter J, Bauer P, Stekly V. System variation of electrical GEN-SET with energy buffer. Proceedings of the 2007 Power Conversion Conference; 2007 April 2-5; Nagoya, Japan. 
Piscataway Township: Institute of Electrical and Electronics Engineers.

47. Pena R, Cardenas R, Escobar E, Clare J, Wheeler P. Control strategy for a doubly-fed induction generator feeding an unbalanced grid or stand-alone load. Electr Power Syst Res. 2009; 79: 355364.

48. Anaya-Lara O, Jenkins N, Ekanayake JB, Cartwright $P$, Hughes M. Wind energy generation: Modelling and control. 1st ed. Chichester: John Wiley \& Sons; 2009.

49. Morren J, De Haan SW. Ridethrough of wind turbines with doubly-fed induction generator during a voltage dip. IEEE Trans Energy Convers. 2005; 20: 435-441.

50. Seman S, Niiranen J, Kanerva S, Arkkio A, Saitz J. Performance study of a doubly fed wind-power induction generator under network disturbances. IEEE Trans Energy Convers. 2006; 21: 883-890.

51. Peng Z, Yikang H. Control strategy of an active crowbar for DFIG based wind turbine under grid voltage dips. Proceedings of the 2007 international conference on electrical machines and systems; 2007 October 8-11; Seoul, Korea. Piscataway Township: Institute of Electrical and Electronics Engineers.

52. Lee JH, Lee SH, Sul SK. Variable-speed engine generator with supercapacitor: Isolated power generation system and fuel efficiency. IEEE Trans Ind Appl. 2009; 45: 2130-2135.

53. Farhan BS, Wang S, Salih HW. Control of variable speed diesel generator using FOC in hybrid system. Int J Control Autom. 2016; 9: 111-122.

54. Iwanski G. Adjustable speed hybrid wind-diesel generation system. In: COMPEL-the international journal for computation and mathematics in electrical and electronic engineering. Bingley: Emerald Publishing Limited; 2011. pp.186-200.

55. Koczara W, Chlodnicki Z, Ernest E, Krasnodebski A, Seliga R, Brown NL, et al. Theory of the adjustable speed generation systems. In: COMPEL-the international journal for computation and mathematics in electrical and electronic engineering. Bingley: Emerald Publishing Limited; 2008. pp.1162-1177.

56. Diaz SA, Silva C, Juliet J, Miranda HA. Indirect sensorless speed control of a PMSG for wind application. Proceedings of the 2009 IEEE International Electric Machines and Drives Conference; 2009 May 3rd-6th; Miami, FL, USA. Piscataway Township: Institute of Electrical and Electronics Engineers.

57. Gajewski P, Pieńkowski K. Performance of sensorless control of permanent magnet synchronous generator in wind turbine system. Power Electron Drives. 2016; 1: 165-174.

58. Chan TF, Wang W, Lai LL. Permanent-magnet synchronous generator supplying an isolated load. IEEE Trans Magn. 2010; 46: 3353-3356.

59. Bolognani S, Venturato A, Zigliotto M. Novel control technique for high-performance dieseldriven AC generator-sets. Proceedings of the 2000 IEE Conference; 2000 September 18-19; London, UK. London: The Institution of Engineering and Technology.

60. Tibola JR, Hausen RB, Martins ME, Pinheiro H. Variable speed and stop-start techniques for engine-generators. Proceedings of the 2015 IEEE 13th Brazilian Power Electronics Conference and 1st Southern Power Electronics Conference; 2015 November 29-December 2; Fortaleza, Brazil. Piscataway Township: Institute of Electrical and Electronics Engineers.

61. Tibola JR. Controle e supervisão de fonte ininterrupta de energia híbrida. Santa Maria: Universidade Federal de Santa Maria; 2017.

62. Tibola JR, Lanzanova TD, Martins ME, Gruendling HA, Pinheiro H. Modeling and speed control design of an ethanol engine for variable speed gensets. Control Eng Pract. 2015; 35: 54-66. 
63. Jean F. Mechanical regulation of electrical frequency in an electrical generation system. Gatineau: Canadian Intellectual Property Office-Patent; 2010; no.2697420.

64. Issa M, Dubé É, Mobarra M, Fiset J, Ilinca A. Modeling and optimization of the energy production based on Eo-synchro application [Internet]. Bedford: IPowerE; 2017. Available from: https://genset-synchro.com/pdf/IDGTE.pdf.

65. Mobarra M, Tremblay B, Rezkallah M, Ilinca A. Advanced control of a compensator motor driving a variable speed diesel generator with rotating stator. Energies. 2020; 13: 2224.

66. Mobarra M, Issa M, Rezkallah M, Ilinca A. Performance optimization of diesel generators using permanent magnet synchronous generator with rotating stator. Energy Power Eng. 2019; 11: 259-282.

67. Chen TF, Sung CK. Design considerations for improving transmission efficiency of the rubber Vbelt CVT. Int J Veh Des. 2000; 24: 320-333.

68. Meiners D. Application of variable speed diesel generator set for village power and wind-diesel applications. Anchorage: Alaska Energy Authority; 2013.

69. Cotrell J. Assessing the potential of a mechanical continuously variable transmission for wind turbines. Golden: National Renewable Energy Lab.; 2005; NREL/CP-500-38212.

70. CVTCORP. Homepage [Internet]. Sainte-Julie: CVTCORP; Available from: https://www.cvtcorp.com/.

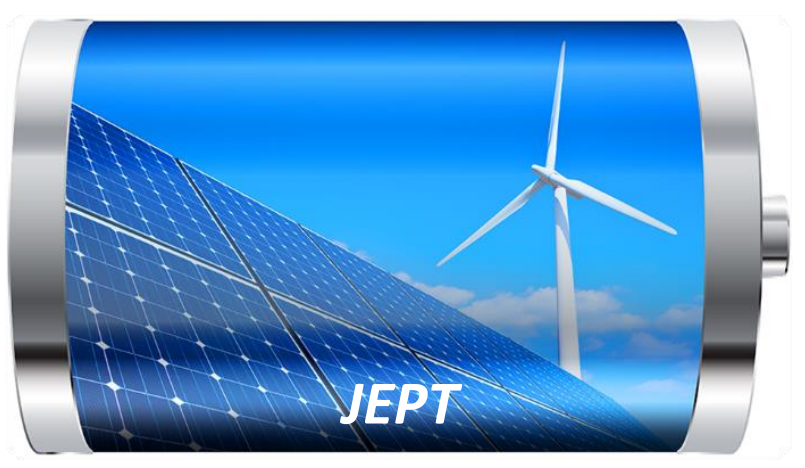

Enjoy JEPT by:

1. Submitting a manuscript

2. Joining in volunteer reviewer bank

3. Joining Editorial Board

4. Guest editing a special issue

For more details, please visit:

http://www.lidsen.com/journal/jept 